\title{
Karakteristik Hasil Tanaman Kedelai Akibat Aplikasi Berbagai Dosis Herbisida Oksifluorfen dan Pendimethalin
}

\section{Characteristics of Soybean Yields Due to Application of Various Dosages of Herbicides oxyfluorphene and pendimethalin}

\author{
Uti Novita Saputri ${ }^{1}$, Siti Hafsah ${ }^{1}$, Hasanuddin ${ }^{1 *}$ \\ ${ }^{1}$ Jurusan Agroteknologi, Fakultas Pertanian, Universitas Syiah Kuala \\ *Corresponding author: hasanuddin@ unsyiah.ac.id
}

\begin{abstract}
Abstrak. Penelitian ini bertujuan untuk mengetahui hasil tanaman kedelai akibat aplikasi herbisida oksifluorfen dan pendimethalin. Penelitian ini telah dilaksanakan dari Mei hingga Agustus 2019 di Desa Rumpeet dan Laboratorium Ilmu Gulma, Fakultas Pertanian, Universitas Syiah Kuala. Desain penelitian ini menggunakaan rancangan acak kelompok faktorial 2 x 5 dengan 3 ulangan. Faktor-faktor yang diteliti adalah jenis herbisida yakni terdapat 2 taraf (Oksifluorfen dan Pendimethalin) dan dosis herbisida yakni terdapat 5 taraf (Kontrol, 0,5, 1, 1,5 dan $2 \mathrm{~kg} \mathrm{b.a} \mathrm{ha}{ }^{-1}$ ). Adapun hasil penelitian yang dilakukan oleh peneliti membuktikan bahwa jenis herbisida dan dosis herbisida tidak mempengaruhi peubah jumlah polong per tanaman, berat biji per tanaman, berat 100 biji, dan hasil biji kering. Tidak ditemukan interaksi antara kedua faktor tersebut terhadap peubah yang diamati. Saran untuk selanjutnya perlu dilakukan penelitian mengenai berbagai variasi jenis dan dosis herbisida lainnya terhadap hasil kedelai.
\end{abstract}

Kata kunci: Herbisida Oksifluorfen, Herbisida Pendimethalin, Dosis, Hasil Kedelai.

Abstract. This research aims to determine the yield of soybean plants due to the application of oxyfluorphene and pendimethalin herbicides. This research was conducted in May to August 2019 in Rumpeet Village and Weed Science Laboratory, Faculty of Agriculture, Syiah Kuala University. The design used was a Randomized Factorial Block Design 2 x 5 with 3 replications. The factors observed were the type of herbicide consisting of 2 levels (Oxyfluorphene and Pendimethalin) and the dosages of the herbicide consisting of 5 levels (Control, 0,5, 1, 1,5 and $2 \mathrm{~kg} \mathrm{a.i} \mathrm{ha}^{-1}$ ). The results of research conducted by researchers prove that the type of herbicide and dosage of herbicide does not affect the number of pods per plant, weight of seeds per plant, weight of 100 seeds, and yield of dried seeds. No interaction was found between these two factors with the observed variables. Suggestions for further research needs to be done on a variety of types and dosages of other herbicides on soybean yields.

Keywords: Oxyfluorphene Herbicide, Pendimethalin Herbicide, Dose, Yields of Soybean.

\section{PENDAHULUAN}

\section{Latar Belakang}

Penyebab rendahnya hasil kedelai adalah infestasi gulma pada tanaman kedelai dari awal periode vegetatif hingga sebelum panen. Rao (2000) menunjukkan bahwa hilangnya hasil ini adalah karena efek nutrisi, persaingan air dan cahaya, dan efek alelopati. Hasanuddin dan Erida (1996) menunjukkan bahwa gulma dapat mengurangi hasil kedelai hingga 53\%. Menurut Sembodo (2010), semakin lama jangka waktu (durasi) keberadaan gulma dan tanaman, semakin besar penurunan hasil karena persaingan. Salah satu langkah untuk mengendalikan gulma dengan mempertimbangkan aspek yang relatif rendah seperti biaya, tenaga dan waktu adalah penggunaan herbisida (Cudney, 1996; Copping 2002; Monaco et al., 2002). 
Penggunaan herbisida dalam budidaya tanaman telah terbukti menghambat pertumbuhan vegetatif dan perkembangan generatif gulma serta menghalangi munculnya gulma yang berasal dari biji. Metode alternatif untuk mengendalikan gulma adalah penggunaan herbisida (Guntoro et al., 2013). Penggunaan herbisida pra tumbuh penting untuk mencegah pembibitan gulma dan seed bank benih gulma, yang pada akhirnya mempengaruhi komponen hasil (Djojosumarto, 2008). Kehadiran gulma pada tanaman kedelai bersaing dengan fasilitas pertumbuhan yang ada (Latifa et al., 2015). Dalam kompetisi memperebutkan nutrisi, meskipun kompetisi tanaman berbeda, jumlah bahan organik yang dapat diproduksi akan tetap jumlahnya, jadi jika gulma tidak dikendalikan, beberapa bahan organik tersebut akan direbut oleh gulma.

Herbisida merupakan bahan kimia yang dapat membunuh atau mengganggu pertumbuhan gulma tanpa mempengaruhi tanaman. Herbisida efektif dalam mengendalikan gulma pada tanaman budidaya dipengaruhi oleh penggunaan dosis yang sesuai (Monaco et al., 2002; Sukman dan Yakup, 2002). Herbisida akan menjadi kurang efektif jika dosis herbisida yang digunakan tidak optimal untuk menghambat pertumbuhan gulma. Gulma akan lebih sensitif terhadap herbisida karena semakin aktif herbisida, sehingga bahan yang lebih aktif diserap (Purnama dan Madkar, 2010). Herbisida yang biasa digunakan dalam tanaman kedelai adalah herbisida oksifluorfen dan pendimetallin yang digunakan pra tumbuh.

Oksifluorfen memiliki sifat selektif dan efektif untuk mengendalikan gulma berdaun lebar dan rerumputan pada kedelai yang dipakai pada saat sebelum tanam (Moenandir dan Kurniawan, 1990). Oksifluorfen adalah herbisida yang dipakai untuk mengendalikan gulma di banyak jenis tanaman. Transpor elektron dalam fotosistem II selama fotosintesis dapat dihambat oleh herbisida oksifluorfen (Tjitrosudirdjo dan Mawardi, 2007). Raoofi et al. (2016) membuktikan bahwa peningkatan herbisida oksifluorfen berdampak pada peningkatan produksi panen. Qasem (2006) membuktikan bahwa perlakuan herbisida oksifluorfen yang paling efektif dan selektif untuk mengendalikan gulma dan meningkatkan pertumbuhan dan hasil tanaman dibandingkan dengan tanpa pengendalian gulma yaitu pada dosis $0,6 \mathrm{~kg}$ b.a ha 1 .

Pendimethalin bersifat selektif dan pra tumbuh yang tergolong herbisida dinitroaniline, rerumputan dan gulma berdaun lebar dapat dikendalikan dengan herbisida pendimethalin. Herbisida Pendimethalin adalah herbisida yang dapat digunakan sebagai herbisida pra tumbuh (Baidhawi, 2013). Pendimethalin menghambat produksi tubulin dengan cara mengganggu pembelahan mitosis (Shaner, 2012). Pendimethalin juga dapat menghambat polimerisasi tubulin. Dimer protein sel yang berpolimerisasi menjadi mikrotubulus merupakan tubulin. Mikrotubulus yang tersusun dari $\alpha$-tubulin dan $\beta$-tubulin merupakan susunan dari mikrotubulus adalah bagian utama dari perangkat mitosis yang mengandung serat gelendong yang dapat memisahkan kromosom selama pembelahan sel (Copping, 2002). Herbisida diaktifkan ketika gulma diterapkan ke tanah sebelum gulma tumbuh atau berkecambah. Pola aksi herbisida pendimethalin adalah racun mitosis yang menghambat perkembangan akar dan kanopi yang baru berkecambah (Sembodo 2010). Penggunaan dosis 0,9-2,0 kg b.a ha ${ }^{-1}$ herbisida pendimethalin dapat mengendalikan gulma tahunan dan gulma berdaun lebar menurut hasil penelitian oleh Tharp dan Kells (2000). Berdasarkan penelitian Buttar et al. (2015) bahwa rerumputan dan gulma berdaun lebar dapat efektif dikendalikan dengan penggunaan herbisida pendimethalin dosis $0,8 \mathrm{~kg}$ b.a ha ${ }^{-1}$.

Tujuan dari penelitian ini adalah untuk mengetahui hasil tanaman kedelai akibat pemberian herbisida Oksifluorfen dan Pendimethalin. 


\section{METODE PENELITIAN}

Penelitian ini sudah dilaksanakan mulai dari bulan Mei-Agustus 2019 di Desa Rumpeet, Kabupaten Aceh Besar dan Laboratorim Ilmu Gulma, Fakultas Pertanian, Universitas Syiah Kuala, Banda Aceh.

\section{MATERI DAN METODE}

\section{Alat dan Bahan}

Alat yang digunakan pada penelitian ini yaitu hand traktor, gembor, knapsack sprayer ukuran $15 \mathrm{~L}$, jarum suntik ukuran 3 dan $5 \mathrm{ml}$, ember, amplop pembungkus, oven, timbangan digital, dan grain moisture meter. Sedangkan bahan yang digunakan pada penelitian ini yaitu benih kedelai varietas Devon 1, herbisida oksifluorfen dan pendimethalin, rhizobium, pupuk anorganik, inseksitisida karbofuran dan deltametrin .

\section{Metode Penelitian}

Proses pengolahan tanah dilakukan sebanyak dua kali. Pertama lahan diolah dengan menggunakan hand tractor dan pengolahan kedua membuat bedengan dengan menggunakan cangkul. Setelah itu, benih ditanam dan diberikan pupuk anorganik. Pengaplikasian pupuk dilakukan sebanyak dua kali, pupuk urea diaplikasikan dua kali yaitu setengah bagian diaplikasikan pada saat tanam dengan cara dicampur dengan pupuk $\mathrm{KCl}$ dan pupuk SP-36. Sedangkan setengah bagian lagi diaplikasikan pada tanaman berumur 30 HST. Pemberian pupuk dilakukan dengan cara larikan. Aplikasi herbisida oksifluorfen dan pendimethalin dilakukan pada saat satu hari setelah tanam. Dosis herbisida yang diaplikasikan sesuai dengan perlakuan. Herbisida diaplikasikan menggunakan knapsack sprayer kapasitas 15 liter. Selanjutnya tanaman dilakukan pemeliharaan seperti penyiraman dan pengendalian hama. Kemudian tanaman di panen saat umur 90 HST.

\section{Jumlah Polong per Tanaman}

Perhitungan polong per tanaman dilakukan setelah kedelai panen, dengan menghitung rata-rata jumlah polong berisi pada tanaman sampel sebanyak 24 tanaman yang ada pada petakan sampel.

\section{Bobot Biji per Tanaman}

Pengamatan bobot biji per tanaman dilakukan dengan menimbang biji kedelai yang memiliki kadar air $\pm 14 \%$ menggunakan timbangan digital. Untuk mendapatkan kadar air biji tersebut maka dikeringanginkan selama 2-3 hari.

\section{Bobot 100 Butir}

Penimbangan bobot 100 butir dilakukan dengan menggunakan timbangan digital. Biji kedelai dikeringanginkan untuk mendapatkan kadar air $\pm 14 \%$

\section{Hasil Biji Kering}

Hasil biji kering dilakukan dengan cara menghitung berat biji kedelai yang sudah dikeringanginkan selama 2-3 hari hingga kadar air mencapai $\pm 14 \%$ pada luasan $180 \times 60$ $\mathrm{cm}$. 


\section{Analisis Statistik}

Analisis data menggunakan analisis ragam yang dilanjutkan dengan uji DNMRT (Duncan New Multiple Range Test) apabila terdapat nilai yang signifikan antar perlakuan pada taraf $5 \%$.

\section{HASIL DAN PEMBAHASAN}

\section{Jumlah Polong Per Tanaman}

Adapun hasil penelitian yang dilakukan peneliti memperlihatkan jenis dan dosis herbisida tidak mempengaruhi bobot biji masing-masing tanaman. Tidak ada interaksi antara jenis herbisida dan dosis terhadap jumlah polong per tanaman. Bobot biji per tanaman akibat jenis dan dosis herbisida dicantumkan pada Tabel 1.

Tabel 1 memperlihatkan bahwa jenis herbisida yang diaplikasikan tidak mempengaruhi komponen polong tanaman. Aplikasi herbisida oksifluorfen dan pendimethalin yang ikut terserap oleh tanaman, akan mempengaruhi fisiologi dalam translokasi fotosintat tanaman sehingga dapat mempengaruhi hasil. herbisida oksifluorfen dapat meracuni sel tumbuhan. Herbisida oksifluorfen juga memiliki kemampuan menghambat respirasi dan fotosintesis, akibatnya dapat mengganggu pembelahan sel, perkembangan dan translokasi bahan makanan di daerah meristem akar dan batang (Lailiyah et al., 2014). Selain itu, herbisida pendimethalin dapat menghambat produksi protein pada tanaman (Shaner, 2012).

Tabel 1. Rata-rata jumlah polong per tanaman akibat jenis dan dosis herbisida
Perlakuan
Bobot 100 Butir

\begin{tabular}{cl}
\hline Jenis Herbisida & $\ldots(\mathrm{g}) \ldots$ \\
oksifluorfen & 31,96 \\
pendimethalin & 30,86 \\
\hline Dosis Herbisida $\left(\mathrm{kg} \mathrm{b} \cdot \mathrm{a} \mathrm{ha}^{-1}\right)$ & \\
0 & 26,12 \\
0,5 & 31,11 \\
1 & 31,09 \\
1,5 & 35,01 \\
2 & 33,74 \\
\hline
\end{tabular}

Dari Tabel 1, dapat dilihat bahwa dosis herbisida yang diterapkan tidak memperlihatkan perbedaan yang signifikan dalam jumlah polong per tanaman, dikarenakan pertumbuhan dan perkembangan tanaman kedelai dapat dipengaruhi oleh semakin tingginya dosis, yang menyebabkan semakin tinggi kapasitas penyerapan tanaman terhadap herbisida. Fuadi dan Wicaksono (2018) mendeskripsikan bahwasanya target gulma dapat dibasmi dengan dosis herbisida yang tepat, tetapi terlalu banyak dosis herbisida dapat merusak tanaman. Menurut pernyataan Yakup (2002), penghambatan pertumbuhan suatu tumbuhan ditentukan oleh dosis herbisida. Tingkat keselektifan herbisida dapat ditentukan pada dosis tertentu, tetapi dengan meningkatnya dosis, maka menjadi tidak selektif. Selain itu, Widyatama et al (2012) juga mengungkapkan bahwa apabila pertumbuhan pada masa vegetatif tanaman kurang maksimal, 
akibatnya ketika memasuki fase generatif terjadi penurunan potensi penghasil asimilat (source) dan berakibat rendahnya pertumbuhan organ pemakai (sink) seperti polong.

Nurjannah (2003) mendeskripsikan bahwasanya ketika tanaman stress air, suhu, cahaya, atau nutrisi maka terjadi gangguan antara hubungan source dan sink. Aktifitas source diperlukan selama siklus hidup tanaman terutama pada periode vegetatif, sedangkan aktivitas sink diperlukan pada periode pembentukan organ-organ yang menghasilkan bunga dan polong. Berat polong berbandig lurus dengan jumlah polong isi dan jumlah biji, semakin banyak jumlah polong dan polong isi maka akan berat polong akan semakin tinggi.

\section{Bobot Biji Per Tanaman}

Adapun hasil penelitian yang dilakukan peneliti memperlihatkan jenis dan dosis herbisida tidak mempengaruhi bobot biji masing-masing tanaman. Tidak ada interaksi antara jenis herbisida dan dosis terhadap bobot biji per tanaman. Bobot biji per tanaman akibat jenis dan dosis herbisida dicantumkan pada Tabel 2.

Tabel 2. Rata-rata bobot biji per tanaman akibat jenis dan dosis herbisida.
Perlakuan
Bobot Biji per Tanaman

\begin{tabular}{cc}
\hline Jenis Herbisida & $\ldots(\mathrm{g}) \ldots$ \\
Oksifluorfen & 6,88 \\
Pendimethalin & 5,71 \\
\hline Dosis Herbisida $\left(\mathrm{kg} \mathrm{b} . \mathrm{a} \mathrm{ha}^{-1}\right)$ & \\
0 & 4,90 \\
0,5 & 6,23 \\
1 & 5,92 \\
1,5 & 7,08 \\
2 & 7,35 \\
\hline
\end{tabular}

Tabel 2 mencantumkan bahwasanya jenis herbisida yang diberikan belum memperlihatkan perbedaan yang signifikan pada berat biji per tanaman. Hal ini dikarenakan menghambatnya pembelahan sel tanaman budidaya yang disebabkan oleh ikut terserap nya herbisida tersebut ke bagian tanaman. Menurut Abadi et al. (2013) terganggunya diferensiasi dan perkembangan tanaman disebabkan masuknya herbisida yang diserap oleh akar yang akan membatasi transfer nutrisi ke tanaman, akibatnya hanya ada sedikit bahan untuk pertumbuhan, sehingga mengganggu diferensiasi dan perkembangan tanaman. Masa pertumbuhan tanaman juga terkait dengan pembelahan sel. Proses akumulasi karbohidrat akan terjadi selama periode generatif, yang akan menentukan bobot biji. Oleh karena itu, periode vegetatif tanaman akan hancur dikarenakan penyerapan herbisida oleh tanaman dan mempengaruhi periode generatif tanaman. Abubakar et al. (2006) menyatakan tingkat penyerapan air, nutrisi dan herbisida yang tinggi dimiliki oleh kedelai yang masih muda sehingga tingkat toksisitasnya tinggi. Selain itu, Erida (1994) menjelaskan bahwa karbohidrat tanaman berfungsi untuk memperpanjang sel yang nantinya akan digunakan tanaman. Ditambahkan oleh Baharsyah et al. (1991) periode generatif terjadi pada saat akhir dari pembungan yang ditandai dengan berhentinya periode vegetative sehinga pada batang kedelai terjadi penimbunan karbohidrat yang berguna untuk pengisian polong dan biji pada kedelai. Egli dan Craft (1996) juga berpendapat bahwa hubungan antara sumber dan limbung dan distribusi fotosintesis sangat 
tergantung pada akumulasi bahan kering (fotosintat) pada benih dan dapat dipengaruhi oleh faktor-faktor eksternal seperti lingkungan, termasuk persaingan dengan gulma.

Dosis herbisida juga belum membuktikan perbedaan yang signifikan dalam berat biji per tanaman (Tabel 2). Hal ini yakni disebabkan meningkatnya laju penyerapan dan translokasi herbisida yang masuk melalui akar atau daun yang disebabkan penyerapan herbisida dosis tinggi pada tanaman kedelai, sehingga pertumbuhan tanaman akan tertekan. Semakin tinggi dosis herbisida, maka semakin besar bahan aktif sehingga tidak efisien. Adnan et al. (2012) mengemukakan bahwasanya jika dosis ditingkatkan, terbukti tidak selektif. Tetapi dosis herbisida tertentu dapat selektif jika dosis yang dipakai sesuai. Sprague dan Hager (2003) menambahkan bahwa, semakin cepat tanaman mengalami gangguan apabila semakin tinggi dosis herbisida yang diserap oleh tanaman. Meilin dan Yardha (2010) juga menambahkan bahwa terlalu banyak dosis herbisida dapat merusak tanaman yang dibudidayakan tetapi jika dosis herbisida yang tepat dapat membunuh gulma target.

\section{Bobot 100 Butir}

Adapun hasil penelitian yang dilakukan peneliti memperlihatkan jenis herbisida tidak berpengaruh signifikan terhadap bobot 100 butir, dan dosis herbisida juga tidak berpengaruh signifikan terhadap bobot 100 butir. Tidak ditemukannya interaksi antara kedua factor tersebut terhadap bobot 100 butir. Berat 100 biji akibat jenis dan dosis herbisida dicantumkan pada Tabel 3.

Tabel 3 mencantumkan bahwasanya jenis dan dosis herbisida tidak mempengaruhi bobot 100 butir. Karena penerapan berbagai jenis dan dosis herbisida, itu tidak mempengaruhi bobot 100 butir. Ketika diterapkan, berbagai jenis dan dosis spesifik diserap oleh tanaman, mempengaruhi pertumbuhan tanaman yang dibudidayakan, terutama ketika pembelahan sel dan fotosintesis terjadi. Selain bobot 100 butir, ukuran bijinya sendiri ditentukan. Oleh karena itu, bobot 100 butir tidak dipengaruhi oleh jenis dan dosis herbisida, tetapi berasal dari kemampuan genetik (internal) tanaman itu sendiri. Semakin baik gen-gen kedelai, semakin baik bobot 100 biji kedelai. Sebuah studi oleh Migawati (2018) menjelaskan bahwa ukuran dan ukuran benih yang kecil dipengaruhi oleh faktor genetik tanaman kedelai. Menurut Anwar dan Alwi (2000), bobot 100 butir mencerminkan berbagai ukuran benih, dan bobot 100 butir lebih dipengaruhi oleh genetika daripada kondisi lingkungan. Somaatmadja (1991) menambahkan bahwa komposisi genetik tanaman dan faktor lingkungan dapat mempengaruhi bobot 100 butir.

Tabel 3. Rata-rata bobot 100 butir akibat jenis dan dosis herbisida.

Perlakuan

\begin{tabular}{cc}
\hline Jenis Herbisida & $\ldots(\mathrm{g}) \ldots$ \\
oksifluorfen & 13,58 \\
pendimethalin & 14,86 \\
\hline Dosis Herbisida $\left(\mathrm{kg} \mathrm{b} \cdot \mathrm{a} \mathrm{ha}^{-1}\right)$ & \\
0 & 12,37 \\
0,5 & 13,41 \\
1 & 14,31 \\
1,5 & 16,24
\end{tabular}


Tinggi tanaman, jumlah cabang, jumlah polong, dan berat biji per tanaman secara signifikan berkorelasi dengan jumlah biji. Setelah meningkatkan banyaknya biji dalam tanaman, nilai variabel dari beberapa faktor ini tinggi, yang secara signifikan mempengaruhi berat biji per tanaman (produk akhir). Namun demikian, diameter batang dan berat 100 biji berkorelasi negatif dengan jumlah biji per tanaman. Oleh karena itu, semakin sedikit biji, semakin kecil berat bijinya, sehingga semakin sedikit pula berat 100 biji.

\section{Hasil Biji Kering}

Adapun hasil penelitian yang dilakukan peneliti menunjukkan bahwa jenis dan dosis herbisida tidak mempengaruhi hasil biji kering. Dan tidak ditemukan interaksi antara kedua faktor ini. Tabel 6 menunjukkan hasil biji kering per petak akibat jenis dan jumlah herbisida yang diaplikasikan.

Tabel 4. Rata-rata hasil biji kering akibat jenis dan dosis herbisida.

Perlakuan

Hasil Biji Kering

\begin{tabular}{cc}
\hline Jenis Herbisida & $\left(\mathrm{g} \mathrm{m}^{-2}\right)$ \\
Oksifluorfen & 165,01 \\
Pendimethalin & 137,12 \\
\hline Dosis Herbisida (kg b.a ha $\left.{ }^{-1}\right)$ & \\
0 & 117,71 \\
0,5 & 149,52 \\
1 & 141,98 \\
1,5 & 169,91 \\
2 & 176,44 \\
\hline
\end{tabular}

Tabel 4 mencantumkan bahwasanya jenis herbisida tidak mempengaruhi hasil biji kering. Ini karena herbisida diserap oleh akar dan daun tanaman, menghentikan proses fotosintesis tanaman, menghambat pertumbuhan dan tidak menghasilkan komponen hasil yang dihasilkan. Semakin baik pertumbuhan tanaman, semakin baik proses fotosintesis, semakin banyak produk fotosintesis yang dihasilkan. Hasanuddin (2003) menjelaskan bahwa penekanan fotosintesis akan mengurangi pembentukan produk fotosintesis, mengurangi energi pembentukan (ATP), dan mengurangi transfer produk fotosintesis ke polong.

Tabel 4 juga mencantumkan bahwasanya dosis herbisida yang diterapkan belum memberikan perbedaan yang signifikan dalam hasil kacang kering. Ini karena penerapan herbisida dosis tinggi dapat menekan pembelahan sel dalam jaringan pintal dan menghambat penyerapan oksigen dalam proses pernapasan (Zimdahl, 2007). Oleh karena itu, sejumlah besar herbisida dapat mempengaruhi tanaman pada berbagai tahap. Sebagaimana dijelaskan oleh Hasanuddin (1998), herbisida dosis tinggi tidak hanya menghambat gulma, tetapi juga menghambat pertumbuhan dan perkembangan tanaman budidaya.

Hasil biji kering terkait dengan jumlah biji per tanaman dan berat biji per tanaman. Sumarno dan Widiati (1994) menjelaskan bahwa hasil kedelai kering tergantung pada ukuran, jumlah dan berat biji. Sebaliknya, jumlah benih tergantung pada jumlah buku subur dan 
jumlah benih per polong. Ada korelasi positif antara hasil dan tinggi tanaman, hasil dan berat biji, hasil dan polong. Solomon dan Bradley (2014) juga menjelaskan bahwa produksi kedelai terkait dengan jumlah polong, jumlah biji, dan berat biji.

\section{KESIMPULAN DAN SARAN}

Jenis herbisida herbisida tidak mempengaruhi peubah jumlah polong per tanaman, bobot biji per tanaman, bobot 100 butir dan hasil biji kering. Dosis herbisida juga tidak mempengaruhi peubah yang diamati. Selain itu, tidak ditemukan nya interaksi antara kedua faktor tersebut terhadap peubah yang diteliti. Saran untuk selanjutnya perlu dikerjakan penelitian mengenai berbagai variasi jenis dan dosis herbisida lainnya terhadap hasil kedelai.

\section{DAFTAR PUSTAKA}

Abadi, I. J., H.T Sebayang dan E. Widaryanto. 2013. Pengaruh jarak tanam den teknik pengendalian gulma pada pertumbuhan dan hasil tanaman ubi jalar (Ipomoea batatas L.) Jurnal Produksi Tanaman. 1(2):8-16.

Abubakar, M., Hasanuddin, M. Rusdi, dan Haswandi. 2006. Efikasi campuran herbisida pendimethalin serta pengaruhnya terhadap gulma dan hasil tanaman kedelai. Jurnal Agrista. 10(3): 158-164.

Adnan, Hasanuddin, dan Manfarizah. 2012. Aplikasi beberapa dosis herbisida glifosat dan paraquat pada sistem tanpa olah tanah (TOT) setra pengaruhnya terhadap sifat kimia tanah. Jurnal Agrista. 16(3): 135-145.

Baharsyah, J.S., D. Suardi dan I. Las. 1991. Hubungan iklim dengan pertumbuhan kedelai. p:87-102. Dalam S. Somaatmadja, M. Ismunadji, Sumarno, M. Syam, S.G. Manurung, dan Yuswardi (ed.) Kedelai. PUSLITBANGTAN, Bogor.

Baidhawi. 2013. Degradasi herbisida pendimethalin pada tanah yang berbeda kandungan bahan organik. Jurnal Agribisnis dan Pengembangan Wilayah. 4(2): 21-30.

Buttar, G. S, N. Aggarwal dan S. Singh. 2015. Efficacy of different herbicides in chickpea (Cicerarietinum L.) under irrigated conditions of Punjab. Indian Journal Weed Science. 40: 169-171.

Copping, L.G. 2002. Herbicide discovery. p:93-113. In R.E.L Naylor (ed.) Weed management handbook. $9^{\text {th }}$ ed. Blackwell Science, Ltd., Oxford, UK.

Cudney, D.W. 1996. Why herbicides are selective. 1996 Symposium Proceedings. California Exotic Pest Plant Council.

Djojosumarto, P. 2008. Teknik Aplikasi Pestisida Pertanian. Kanisius, Yogyakarta.

Egli, D. B., and S.J.B Craft. 1996. Soybean. p. 12-124. In E. Zamki and A.A, Schaffer (ed). Photo asimilate distribution in plant and crops: source-sink relationship. p. 595-623. Marcel Dekker. Inc. New York.

Erida, G. 1994. Masa Kritis Tanaman Kedelai (Glycine max L. Merrill) akibat persaingan teki. Laporan hasil penelitian. Universitas syiah kuala, Banda Aceh. 
Fuadi, T. R., dan K. P. Wicaksono. 2018. Aplikasi herbisida berbahan aktif atrazin dan mesotrion terhadap pengendalian gulma dan hasil tanaman jagung manis (Zea mays L. Saccharata) varietas bonanza. Jurnal Produksi Tanaman. 6(5): 767-774. Hasanuddin, 1998. Pertumbuhan gulma dan tanaman kedelai (Glycine max (L.) Merrill) akibat herbisida trifluralin; Pengaruh waktu aplikasi dan campuran herbisida. Jurnal Agrista. 2(3): 251-257.

Guntoro, D., K. Agustina dan Yursida. 2013. Efikasi herbisida penoksulam pada budidaya padi sawah pasang surut untuk intensifikasi lahan suboptimal. Jurnal Lahan Suboptimal. 2(2): 144-150.

Hasanuddin, 1998. Pertumbuhan gulma dan tanaman kedelai (Glycine max (L.) Merrill) akibat herbisida trifluralin; Pengaruh waktu aplikasi dan campuran herbisida. Jurnal Agrista. 2(3): 251-257.

Hasanuddin. 2003. Hasil tanaman kedelai dan pola persistensi akibat herbisida clomazone dan pendimethalin bervariasi dosis pada kultivar argomulyo dan wilis. Disertasi. Program Pascasarjana Universitas Padjajaran, Bandung.

Hasanuddin, dan G. Erida. 1996. Penentuan periode kritis tanaman kedelai [(Glycine max L.) Merrill] akibat adanya persaingan dengan gulma. Hal: 14-16. Dalam N. Sriyani (eds.) Prosiding Konferensi Nasional XIII dan Seminar Ilmiah HIGI. Bandar Lampung, 5-7 November 1996.

Lailiyah, N. Wiharyanti, E. Widaryantodan K. P. Wicaksono. 2014. Pengaruh periode penyiangan gulma terhadap pertumbuhan dan hasil tanaman kacang panjang (Vigna sesquipedalis L.). Jurnal Produksi Tanaman. 2(7): 606-612.

Latifa, Y. Rio, M. dawam, dan W. Eko.2015. Pengaruh pengendalian gulma terhadap tanaman kedelai (Glycine $\max$ L. Merrill) pada sistem olah tanah. Jurnal Produksi Tanaman. 3(4): 311-320.

Meilin dan Yardha. 2010. Efektivitas Aplikasi Beberapa Herbisida Sistemik Terhadap Gulma pada Perkebunan Kelapa Sawit Rakyat. Jurnal Agroekoteknologi, 2 (1), 1-6.

Migawati, S. W. 2018. Potensi terang bulan, kirinyuh, dan nimba sebagai mulsa pada tanaman kedelai. Skripsi. Program Studi Agroteknologi Fakultas Pertanian Universitas Syiah Kuala, Banda Aceh.

Moenadir, J. dan Kurniawati. 1990. Toleransi tanaman kedelai varietas willis dan grinting pada oksifluorfen (Goal 2E). Jurnal Agrivita 14(1): 24-29.

Monaco, T. J., S. C. Weller dan F. M. Ashton. 2002. Weed Science: Principles and Practices$4^{\text {th }}$ ed. John Wiley \& Son, Inc, New York.

Nurjannah, U. 2003. Pengaruh dosis herbisida glifosat dan 2,4 -D terhadap pergeseran gulma dan tanaman kedelai tanpa olah tanah. Jurnal Ilmu - Ilmu Pertanian Indonesia. 5(1): 27 -33 .

Purnama S dan Madkar OR. 2010. Respon gulma dan kedelai berbagai tingkat kerapatan akibat aplikasi herbisida glifosat-kalium pada sistem tanpa olah tanah. Hal: 63-73. 
Dalam D. Kurniadie dan D. Widayat (Eds.). Prosiding Seminar Nasional XVIII HIGI, Bandung. 30-31 Oktober 2009.

Qasem, J. R. 2006. Weed control in cauliflower (Brassica oleracea var. botrytis) with Herbicide. J. Crop, Prot, 26: 1013-1020.

Rao, V. S. 2000. Principles of weed science. $2^{\text {nd }}$ ed. Science Publishers, Inc., Enfield, NH.

Raoofi, M., S. Mahzari, M. A. Baghestani. 2016. Effect of appliying different herbicides dosages oxyfluorfen and trifuralin on morphological economical and biological yield of garlic (Allium sativum L.). Journal of Advanced Biological and Biomedical Research. 4(2): 136-142.

Sembodo, D. R. J. 2010. Gulma dan Pengolaannya. Graha Ilmu, Yogyakarta

Shaner, D. L. 2012. Field dissipation of sulfentrazone and pendimethalin in Colorado. Weed Technology, 26(4):633-637.

Solomon, C. and P.K. Singh. 2018. Influence of application timing and sublethal rates of synthetic auxin herbicides on soybean. Journal of Weed Technology. 28(3): 454-464.

Sprague, C.L., and A.G. Hager. 2003. Herbicide persistence and how to test for residues in soils. Illinois Agricultural Pest Management Handbook. University of Illinois. Urbana, IL.

Sukman, Y dan Yakup. 2002. Gulma dan Teknik Pengendaliannya. PT Radja Grafindo Persada, Jakarta.

Sumarno dan Widiati. 1994. Seleksi hasil kedelai berdasarkan bobot berangkasan dan indeks panen. Penelitian Pertanian. 42: 64-67.

Tharp, B.E., and J.J. Kells. 2000. Effect of soil-applied herbicides on establishment of cover crop species. Weed Technology, 14:596-601.

Tjitrosoedirdjo, S. S. dan I. Mawardi. 2007. 75 Important Invansive Plant Spesies in Indonesia. SEAMEO BIOTROP, Bogor.

Widyatama, C. E., Tohari dan R. Rogomulyo. 2012. Periode kritis kedelai hitam (Glycine max (L.) Merril) terhadap gulma. Jurnal Vegetalika 1(1): 32-41.

Yakup, Y. S. 2002. Gulma dan Teknik Pengendaliannya. Raja Grafindo Persada, Jakarta.

Zimdahl, R.L. 2007. Fundamentals of weed science. Academic Press, Inc., San Diego, CA. 